\title{
Lymphatic Vascularization in Primary Breast Cancer: HER2 Overexpressing Tumors Contain More Lymphatics than Steroid Receptor Positive, Triple-Positive and Triple Negative Breast Carcinomas
}

\author{
Primer Meme Kanserinde Lenfatik Vaskülarizasyon: \\ HER2 Overekspresyonu Gösteren Tümörler; Steroid Reseptör-Pozitif, \\ Triple-Pozitif ve Triple-Negatif Tümörlere Kıyasla Daha Fazla Lenfatik \\ Damar İçermektedir
}

\author{
Savelina POPOVSKA, Ivan IVANOV
}

Departments of Pathology, Medical University-Pleven, PLEVEN, BULGARIA

\section{ABSTRACT}

Objective: The aim of this study was to examine the relationship between the immunohistochemical subtypes of invasive breast cancer and lymphatic vascularization.

Material and Method: One hundred and seventy nine cases of randomly selected invasive breast cancer patients, surgically treated between 2004 and 2007, were retrospectively studied. These were classified into steroid receptor positive (steroid receptor positive/ HER2 negative), triple positive (steroid receptor and HER2 positive), triple negative (steroid receptor and HER2 negative) and HER2 overexpressing (steroid receptor negative /HER2 positive) carcinomas. Appropriate immunostaining and in-situ hybridization techniques were applied and results were statistically analyzed.

Results: The median intra-tumor lymphatic vascular density and the median intra-tumor relative lymphatic vascular area were found to differ significantly among the studied groups of breast cancer (KW $=49.8611 ; \mathrm{p}<0.0001$ and KW $=21.5122 ; \mathrm{p}=0.0001$ respectively). There was no significant difference in the incidence rate of axillary node involvement among the studied groups of breast cancer $\left(\chi^{2}=1.66\right.$; $\mathrm{Df}=3 ; \mathrm{p}=0.6460$ ).

Conclusion: The present study indicates that HER2 overexpressing breast carcinomas have a consistent increase of intra-tumor lymphatic vessel counts as compared to all other subtypes. It is suggested that the newly formed vessels are probably not the only essential factor for lymphogenic spread of HER2 overexpressing breast carcinomas as they are not related to an increased incidence of lymph node metastases compared to the other studied subgroups.

Key Words: Breast neoplasms, Estrogen receptor, Progesterone receptor, HER2, Lymphangiogenesis

(Turk Patoloji Derg 2014, 30:124-132)

Received : 18.11.2013 Accepted : 27.01.2014

\section{Öz}

Amaç: Bu çalışmada, meme kanserlerinin immünhistokimyasal alt tipleri ile lenfatik vaskülarizasyon arasındaki ilişkinin saptanması amaçlanmıştır.

Gereç ve Yöntem: Çalışmaya 2004-2007 yılları arasında opere edilmiş, rastlantısal olarak seçilen 179 invaziv meme kanserli hasta alındı. Hastalar, steroid reseptör pozitif (steroid reseptör pozitif/ HER2 negatif), triple pozitif (steroid reseptör pozitif ve HER2 pozitif), triple negatif (steroid reseptör ve HER2 negatif) ve HER2 aşır1 ekspresyonlu (steroid reseptör negatif ve HER2 pozitif) olarak 4 alt tipte siniflandı. Olgularda gerekli immünhistokimyasal ve in situ hibridizasyon incelemeler yapilarak, bulgular istatistiksel olarak değerlendirildi.

Bulgular: Ortanca intratümöral lenfatik damar yoğunluğu ve ortanca intratümör lenfatik damar alanı, alt tipler arasında anlamlı olarak değişkenlik gösterdi $(\mathrm{KW}=49.8611 ; \mathrm{p}<0.0001$ ve $\mathrm{KW}=21.5122$; $\mathrm{p}=0.0001)$. Alt tipler arasında aksiller lenf nodu tutulumu açısından anlamlı farklılık saptanmadı $(\chi 2=1.66 ; \mathrm{Df}=3 ; \mathrm{p}=0.6460)$.

Sonuç: Bulgularımız HER2 aşırı eksprese eden meme karsinomlarının diğer alt tiplere kıyasla yüksek sayıda intratümöral lenfatik damar içerdiğini göstermektedir. Tümör içinde yeni oluşan damarların lenfojen yayılım açısından yegane faktör olmadığını ileri sürmekteyiz. Çünkü bu özellikleri gösteren tümörlerde diğer alt tiplere kıyasla lenf nodu metastazı sıklığında bir artış saptanmamıştır.

Anahtar Sözcükler: Meme tümörleri, Östrojen reseptörü, Progesteron reseptörü, HER2, Lenfanjiyogenez

Correspondence: Savelina POPOVSKA

Medical University-Pleven, Department of Pathology, PLEVEN, BULGARIA

E-mail: sapopovska@yahoo.com Phone: +35 964886127 


\section{INTRODUCTION}

There are several classifications of breast carcinomas based on their immunohistochemical expression profile for estrogen receptor (ER)/ progesterone receptor (PgR), HER2, epidermal growth factor receptor (EGFR), cytokeratin (CK) 5/6 and Ki-67 (1-6). Accordingly, breast carcinomas (BC) are divided into subtypes which are believed to be relevant to prognosis $(2,5,7,8)$. Both triple negative and HER2 overexpressing / ER negative carcinomas are characterized by poor prognosis (9). Potential factors that may contribute to the unfavorable prognosis of HER2 overexpressing tumors are increased angiogenesis $(10,11)$ and lymphangiogenesis $(12,13)$.

Raica et al. have reported high levels of expression of vascular endothelial growth factor (VEGF)-C/vascular endothelial growth factor receptor (VEGFR)-3 and D2-40 in HER2 and luminal B types, and low rates of expression in basal-like type. In addition, the same authors have found the lowest value of both intratumor and peritumor lymphatic microvessel density (LVD) in normal-like type of BC (14). Presently, it is not clear whether some types of BCs display a consistent increase of lymphatic vascularization (LV). In addition there is no evidence that LVD is associated with an increase in the metastatic potential via the lymphatic pathway.

The purpose of this study was to find any relation between different subtypes of invasive breast cancer, subdivided according to their steroid receptor (ER, PgR) and HER2 status, and lymphatic vascularization present within or around the primary tumor, using immunohistochemistry.

\section{MATERIALS and METHODS}

Patients: One hundred and seventy nine randomly selected cases of invasive BC, surgically treated between 2004 and 2007 in the University Hospital in Pleven, Bulgaria, were retrospectively studied. Archival formalin fixed paraffin embedded tissues as well as pathology reports and case- history charts were retrieved and analyzed. All patients were female, ranging in age between 30.0 and 81.0 years (average 60.4 yrs).

The 179 cases studied included 147 (82.12\%) invasive ductal carcinomas, 26 (14.52\%) invasive lobular carcinomas, 3 (1.68 \%) mucinous carcinomas, and 3 (1.68 \%) medullary carcinomas. Tumors were staged according to the AJCC (15) and graded according to the Elston \& Ellis criteria (16).

Immunohistochemistry: All cases were immunostained for ER, PgR, HER2 and D2-40. Details concerning the primary antibodies used are presented in Table I. All immunostains were manually processed. The FLEX EnVISION (DAKO) method was used for immunohistochemical staining. Immunohistochemical reactions were developed with 3-3' diaminobenzidine and sections were counterstained with Mayer hematoxylin.

Evaluation of staining: Manual readings were carried out independently by the two investigators (S.P. and I.I.). Discordances were discussed until a consensus was reached. HER2 was accepted as positive if immunohistochemistry (IHC) reaction for HER2 was complete, uniform, and presented intense membrane staining of $>30 \%$ of invasive tumor cells $(3+)$, or if there were more than six HER2 gene copies per nucleus in $>50 \%$ of the cancer cells on CISH. If IHC staining for HER2 was complete, uniform membrane, with moderate intensity of $>30 \%$ of invasive tumor cells result was considered equivocal - (HER2 - 2+), and additional testing with $\mathrm{CISH}$ was performed. Cases with incomplete, weak (1+) or missing (0) immunostaining on IHC, as well as cases with less than five HER2 gene copies per nucleus, were considered negative $(9,17)$. ER and PgR were considered positive if $>10 \%$ of invasive tumor cells displayed weak, moderate or strong immunostaining (18). Vessels were interpreted as lymphatic structures if most of the lining cells showed intermediate to strong cytoplasm immunostaining for D2-40 and lumina were devoid of red blood cells.

Table I: General information concerning the used primary antibodies: clone, working concentration, manufacturer and antigen retrieval method used

\begin{tabular}{|l|c|c|c|c|}
\hline Primary antibody & Clone & Dilution & Manufacturer & Antigen retrieval \\
\hline HER2 & $\begin{array}{c}\text { c-erbB-2 } \\
\text { oncoprotein }\end{array}$ & $1: 250$ & DAKO & $\begin{array}{c}\text { Heat mediated - pressure cooking; } \\
16 \mathrm{psi} \text { t }=124^{\circ} \mathrm{C} \text {; Time 1 min }\end{array}$ \\
\hline ER & SP1 $\alpha$ & Ready to use & DAKO & $\begin{array}{c}\text { Heat mediated - pressure cooking; } \\
16 \mathrm{psi} \mathrm{t}=124^{\circ} \mathrm{C} \text {; Time 1 min }\end{array}$ \\
\hline PgR & PgR 636 & Ready to use & DAKO & $\begin{array}{c}\text { Heat mediated - pressure cooking; } \\
16 \mathrm{psi} \mathrm{t}=124^{\circ} \mathrm{C} \text {; Time } 1 \text { min }\end{array}$ \\
\hline D2-40 & D2-40 & $1: 100$ & DAKO & $\begin{array}{c}\text { Heat mediated - pressure cooking; } \\
16 \mathrm{psi} \mathrm{t}=124^{\circ} \mathrm{C} \text {; Time } 1 \text { min }\end{array}$ \\
\hline
\end{tabular}


CISH: CISH was performed on $4 \mu \mathrm{m}$ tissue sections. Only cases with HER2 2+ receptor status were retested with the CISH method. The tissue sections were treated in accordance with the protocol provided by the manufacturer (CISH $^{\mathrm{m}}$ Tissue Pretreatment Kit, Zymed). The CISH signals were visualized and assessed using a bright-field microscope at magnification $10 \mathrm{x} / 60 \mathrm{x}$ objectives.

IHC classification of breast tumors based on ER, PgR and HER2: IHC markers and CISH were used to define the breast cancer subtypes which were categorized as: Steroid receptor positive (SRP) - (ER+ and/or PR+, HER2 - ), Triple positive tumors (TPT) (ER+ and /or PR+, HER2+), HER2 overexpressing (HER2+, ER- and/or PR-) and Triplenegative tumors (TNT) (ER-,PR- and HER2-), modified from the one suggested by Onitilo AA et al. (9).

Definition of LVI : Lymphatic vascular invasion (LVI) was assessed on D2-40 stained slides. Any tumor-cell clusters present within D2-40 positive vessels were accepted as LVI.

Lymphatic vascularity assessment: The number of lymphatic vessels was assessed by the two investigators. D2-40 stained slides were covered by a grid $20 \times 20 \mathrm{~mm}$, composed of 25 small squares $4 \mathrm{x} 4 \mathrm{~mm}$ each (Figure 1A). These slides were then scanned at low magnification $40 \mathrm{x}$ (4x objective 10x eye-peace). The LV count was assessed in each square and the result was filled in a specially developed individual hot-spot identification table (Figure 1B). If differences in vascular counts were overestimated by +/- $10 \%$, counting was repeated.

After hot spots had been identified, the highest possible intratumor (inside the tumor and its stroma) and peritumor (at the tumor front of invasion and around the tumor) lymphatic vascular density (LVD) was estimated by the two investigators at magnification 100x (10x objective 10x eyepeace). If differences in vascular counts were overestimated by $+/-10 \%$, the counting was repeated.

Areas with the highest vascularization were photographed using an Olympus BX 40 microscope, equipped with an Olympus digital camera 5050 zoom and digital images were saved. A computerized image analysis was performed using Image Tool software. After spatial calibration of the software, images were used for the calculation of intra- and peritumor relative lymphatic vascular area (RLVA). RLVA was calculated as the area occupied by lymphatic vessels as related to the whole area of the field $\left(1.2 \mathrm{~mm}^{2}\right)$. For optimal results, measurement was performed manually.

Statistical analysis: Statistical analysis was performed with the Statgraphics plus 2.0 software package. Comparison of all parametric variables was statistically studied as it follows: initially, normality of the studied variables was tested with Kolmogorov - Smirnov test. Since all parametric variables were not with normal distribution, the Kruskal-Wallis test was used for comparing lymphatic vascularization parameters. The relation of the IHC determined subtypes of breast cancer to lymphatic vascularization parameters was initially tested with the Kruskal-Wallis test. After analyzing lymphatic vascularization parameters, a posthoc analysis test was carried out by applying the MannWhitney (Wilcoxon) W two-tailed test (Statgraphics plus 2.0 software package) to identify the presence of significant differences between the lymphatic vascularization observed in the studied subgroups of breast cancer.

The relation of axillary node status to lymphatic vascularization parameters was tested using Kruskal-Wallis test. Differences in non-parametric variables were tested

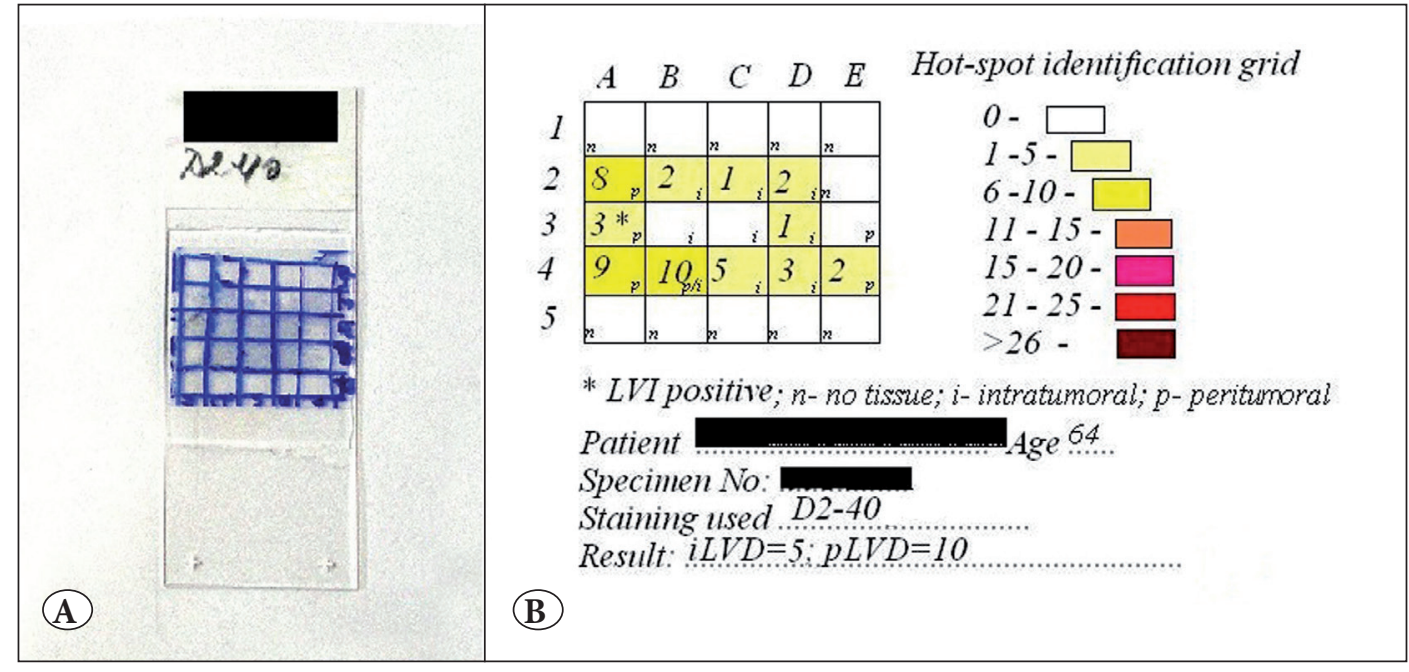

Figure 1: A) An example of covering glass stamped with 20x 20mm grid. Any grid printed on transparent material (plate) can be mounted instead B) Individual hot-spot identification table - an example of the hot-spot identification table used in this study. 
using the Chi-square test. Probability values of $\mathrm{p}<0.05$ were considered to represent a significant difference for the Kruskal-Wallis test and Chi-square test and probability values of $\mathrm{p}<0.0083$ for the Mann-Whitney (Wilcoxon) W, after Bonferroni correction was applied.

\section{RESULTS}

Intratumor lymphatic vessels were mostly present in the tumor margins of $\mathrm{BC}$ showing infiltrative growth pattern in SRP, TPT and HER 2 subtypes (Figure 2A,B). Tumors with predominantly pushing growth (some of the TNT) had scanty intratumor lymphatic vessels (Figure 2C).

Intratumor lymphatic vessels appeared predominantly as vascular clefts, while peritumor lymphatic vessels were characterized by well-evident to dilated structures. In 48 (26.82\%) of the cases, lymphatic vessels were harboring
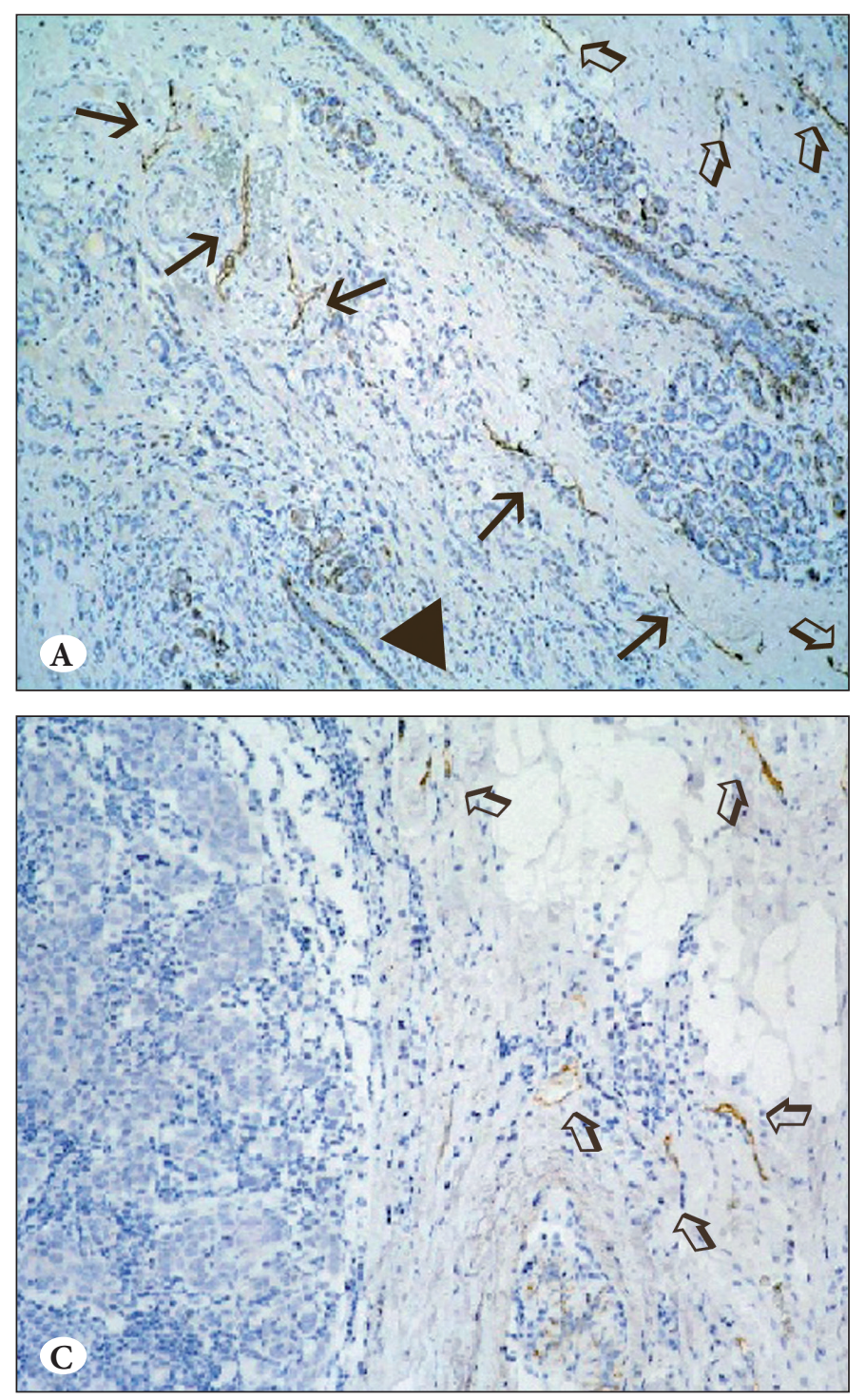

Figure 2: A) Steroid receptor positive breast carcinoma - a predominantly infitrative growth pattern was observed. Co-opted terminal ducto-lobular unit (arrow head) as well as lymphatic vessels that looked collapsed (arrows) were observed in the periphery of the tumor. The lymphatic vessels in the periphery of the tumor were generally preserved, almost similar in size and morphology to normal lymphatic vessels (contour arrows) (D2-40; x100).

B) HER2 overexpressing breast carcinoma - infiltrative growth pattern was observed. Lymphatic vessels were seen in the tumors' periphery (arrows). Most of those vessels seemed somewhat smaller than normal and collapsed (D2-40; x100).

C)Triple-negative breast cancer - presented with typical "pushing margin" growth pattern. The tumor had no intratumor lymphatic vessels; peritumor lymphatic vessels are designated with (contour arrows) (D2-40; x100). 
Table II: Comparison between the lymphatic vascularization observed in the studied subgroups of breast cancer, divided on the basis of IHC profile for ER, PgR and HER2

\begin{tabular}{|c|c|c|c|c|c|c|}
\hline & SRP-TPT & SRP-HER2 & SRP-TNT & TPT-HER2 & TPT-TNT & HER2-TNT \\
\hline \multirow{2}{*}{ ILVD } & $\begin{array}{c}\mathrm{W}=823.0 ; \\
\mathrm{p}=0.8954(\mathrm{NS})\end{array}$ & $\begin{array}{c}\mathrm{W}=2700.0 ; \\
\mathrm{p}<0.0001(\mathrm{~S})\end{array}$ & $\begin{array}{c}\mathrm{W}=1627.5 ; \\
\mathrm{p}=0.7226(\mathrm{NS})\end{array}$ & $\begin{array}{c}\mathrm{W}=540.0 ; \\
\mathrm{p}<0.0001(\mathrm{~S})\end{array}$ & $\begin{array}{c}\mathrm{W}=315.0 ; \\
\mathrm{p}=0.9907(\mathrm{NS})\end{array}$ & $\begin{array}{c}\mathrm{W}=202.5 ; \\
\mathrm{p}<0.0001(\mathrm{~S})\end{array}$ \\
\hline \multirow{2}{*}{ IRLVA } & $\mathrm{W}=801.0 ;$ & $\mathrm{W}=2389.5 ;$ & $\mathrm{W}=1627.5 ;$ & $\mathrm{W}=513.0 ;$ & $\mathrm{W}=330.0 ;$ & $\mathrm{W}=472.0 ;$ \\
& $\mathrm{p}=0.9315(\mathrm{NS})$ & $\mathrm{p}<0.0001(\mathrm{~S})$ & $\mathrm{p}=0.7230(\mathrm{NS})$ & $\mathrm{p}=0.0003(\mathrm{~S})$ & $\mathrm{p}=0.7371(\mathrm{NS})$ & $\mathrm{p}=0.0547(\mathrm{NS})$ \\
\hline \multirow{2}{*}{ PLVD } & $\mathrm{W}=760.5 ;$ & $\mathrm{W}=1620.0 ;$ & $\mathrm{W}=1312.5 ;$ & $\mathrm{W}=351.0 ;$ & $\mathrm{W}=292.5 ;$ & $\mathrm{W}=540.0 ;$ \\
& $\mathrm{p}=0.6849(\mathrm{NS})$ & $\mathrm{p}=0.9978(\mathrm{NS})$ & $\mathrm{p}=0.1475(\mathrm{NS})$ & $\mathrm{p}=0.6212(\mathrm{NS})$ & $\mathrm{p}=0.6773(\mathrm{NS})$ & $\mathrm{p}=0.3003(\mathrm{NS})$ \\
\hline \multirow{2}{*}{ PRLVA } & $\mathrm{W}=783.0 ;$ & $\mathrm{W}=1917.0 ;$ & $\mathrm{W}=1815.0 ;$ & $\mathrm{W}=472.0 ;$ & $\mathrm{W}=360.0 ;$ & $\mathrm{W}=720.0 ;$ \\
& $\mathrm{p}=0.8270(\mathrm{NS})$ & $\mathrm{p}=0.1088(\mathrm{NS})$ & $\mathrm{p}=0.1877(\mathrm{NS})$ & $\mathrm{p}=0.0059(\mathrm{~S})$ & $\mathrm{p}=0.4017(\mathrm{NS})$ & $\mathrm{p}=0.3008(\mathrm{NS})$ \\
\hline
\end{tabular}

SRP: Steroid receptor positive, TNT: Triple negative tumors, TPT: Triple positive tumors, NS: Not significant, S: Significant, W: (Wilcoxon rank-sum test), ILVD: Intratumor lymphatic vascular density, IRLVA: Intratumor relative lymphatic vascular area, PLVD: Peritumor lymphatic vascular density, PRLVA: Peritumor relative lymphatic vascular area.

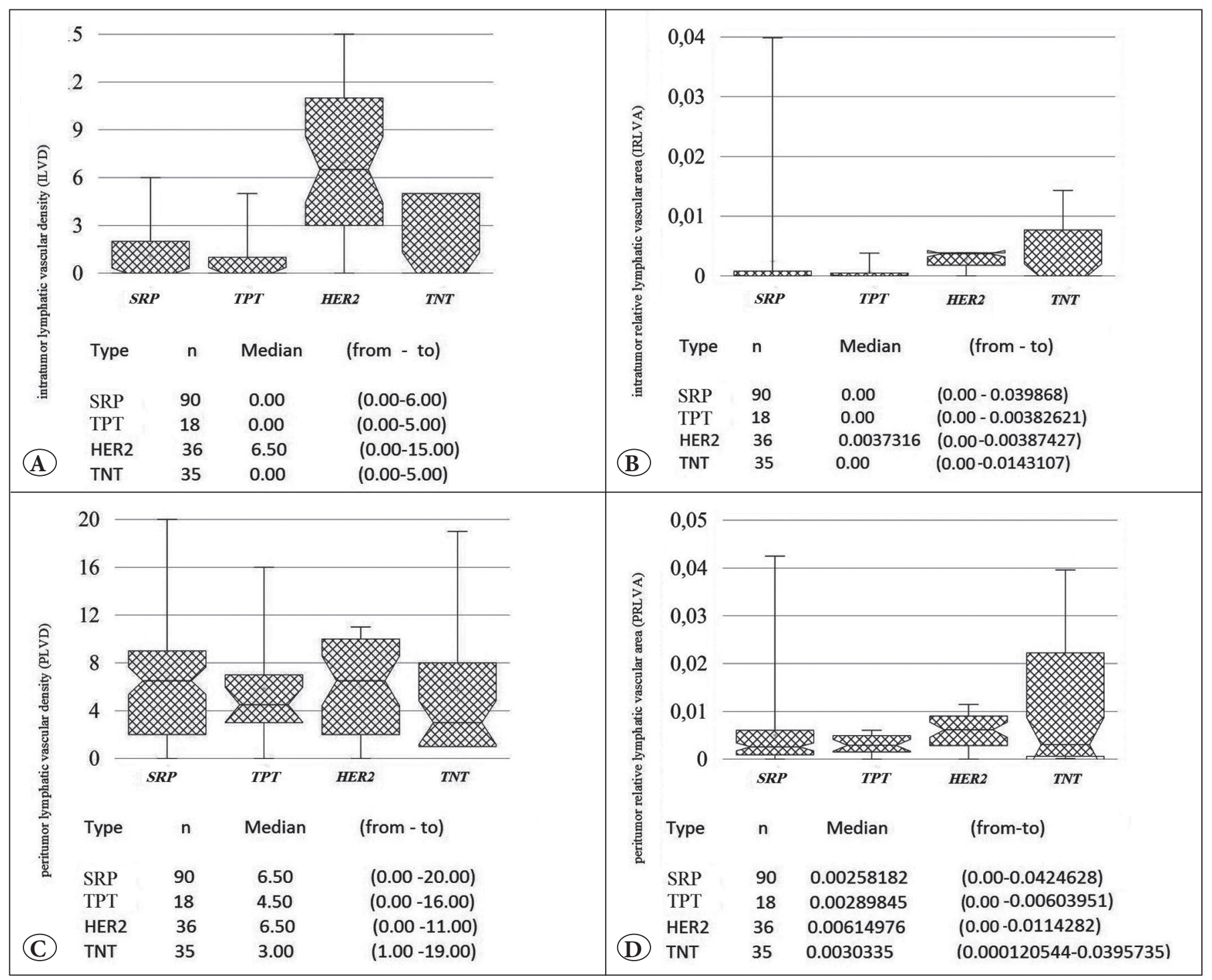

Figure 3: Quantitative comparison of lymphatic vascularization of different molecular subtypes of breast cancer divided on the basis of IHC. A) Intratumor lymphatic vascular density (ILVD), B) Intratumor relative lymphatic vascular area (IRLVA), C) Peritumor lymphatic vascular density (PLVD), D) Peritumor relative lymphatic vascular area (PRLVA). 
compared to the median values of IRLVA 0.00 (no intratumor lymphatic vessels) in SRP and TPT subtypes. No significant difference was found between HER2 overexpressing tumors and TNT as well as between SRP- TPT, SRP- TNT and TPTTNT. Details are presented on Table II.

Some not statistically significant differences in the median peritumor lymphatic vascular density (PLVD) were found among the different molecular subtypes of breast cancer considered ( $\mathrm{KW}=2.11619 ; \mathrm{p}=0.54864$ ) (Figure 3C). No differences were found in the median values for PLVD when the different subgroups of $\mathrm{BC}$ were compared. Details are presented on Table II.

In general, no significant differences were found in the median peritumor relative lymphatic vascular area (PRLVA) among the subtypes of breast cancer divided on the basis of IHC (KW $=4.89442 ; \mathrm{p}=0.179691)$ (Figure 3D). From all the analyzed groups only TPT and HER2 were found to differ significantly in their median values of PRLVA. Details are presented on Table II.

The distribution of tumor size in the studied groups is presented on Table III. Steroid receptor positive tumors and TPT's were likely to be predominantly low grade compared with HER2 overexpressing tumors and triplenegative $\mathrm{BC}$ that were predominantly high grade lesions. The distribution of the studied cases by grade and subtypes of breast cancer, divided on the basis of IHC, is presented on Table III. The age of initial clinical presentation was different in the different breast cancer subtypes (Table III).

No correlation was found between lymph node status and the immunophenotype of the tumor (Table III). There was no significant difference in the incidence of lymphatic vascular invasion found in tumors with different immunophenotypes (Table III).

Table III: Correlation between some of the main predictive factors in breast cancer and immunophenotype

\begin{tabular}{|l|c|c|r|r|c|}
\hline & SRP & \multicolumn{1}{|c|}{ TPT } & \multicolumn{1}{c|}{ HER2 } & \multicolumn{1}{c|}{ TNT } & Statistical test \\
\hline T1 & $42(23.46 \%)$ & $9(5.03 \%)$ & $9(5.03 \%)$ & $15(8.38 \%)$ & chi - squere test \\
T2 & $36(20.11 \%)$ & $9(5.03 \%)$ & $27(15.08 \%)$ & $20(11.17 \%)$ & $\chi^{2}=21.51 ; \mathrm{Df}=6 ;$ \\
T3+T4 & $12(6.70 \%)$ & $0(0.00 \%)$ & $0(0.00 \%)$ & $0(0.00 \%)$ & $\mathrm{p}=0.0015$ \\
\hline $\mathrm{N}-$ negative & $36(20.11 \%)$ & $6(3.35 \%)$ & $18(10.06 \%)$ & $15(8.38 \%)$ & chi - squere test \\
$\mathrm{N}$ - positive & $54(30.17 \%)$ & $12(6.70 \%)$ & $18(10.06 \%)$ & $20(11.17 \%)$ & $\chi^{2}=1.66 ; \mathrm{Df}=3 ; \mathrm{p}=0.6460$ \\
\hline G1 & $30(16.76 \%)$ & $3(1.68 \%)$ & $0.0(0.00 \%)$ & $0.0(0.00 \%)$ & \\
G2 & $51(28.49 \%)$ & $12(6.70 \%)$ & $27(15.08 \%)$ & $30(16.76 \%)$ & not performed \\
G3 & $9(5.03 \%)$ & $3(1.68 \%)$ & $9(5.03 \%)$ & $5(2.79 \%)$ & \\
\hline LVI - negative & $69(38.55 \%)$ & $15(8.38 \%)$ & $27(15.08 \%)$ & $20(11.17 \%)$ & chi - squere test \\
LVI - positive & $21(11.73 \%)$ & $3(1.68 \%)$ & $9(5.03 \%)$ & $15(8.38 \%)$ & $\chi^{2}=6.15 ; \mathrm{Df}=3 ; \mathrm{p}=0.1045$ \\
\hline \multirow{2}{*}{ Age } & $\mathrm{n}=90$ & $\mathrm{n}=18$ & $\mathrm{n}=36$ & $\mathrm{n}=35$ & $\mathrm{Kruskal-Wallis} \mathrm{test}$ \\
& $66.5(46-81)$ & $53.5(30-76)$ & $61.0(40-72)$ & $56.0(38-66)$ & $\mathrm{K}-\mathrm{W}=32.074 ; \mathrm{p}<0.0001$ \\
\hline
\end{tabular}

SRP: Steroid receptor positive, TPT: Triple positive tumors, TNT: Triple negative tumors.

Table IV: Lymphatic vascularization parameters and their relation to axillary lymph node status

\begin{tabular}{|c|c|c|c|c|}
\hline & Lymph node status & $\mathbf{n}$ & Me $(\mathbf{m i n}-\mathbf{m a x})$ & Kruskal-Wallis test \\
\hline \multirow{2}{*}{ ILVD } & N negative & 75 & $0.0(0.0-6.0)$ & K-W=20.1232; \\
& N positive & 104 & $1.5(0.0-15.0)$ & $\mathrm{p}<0,0001$ \\
\hline \multirow{2}{*}{ IRLVA } & N negative & 75 & $0.0(0.0-0.00990234)$ & $\mathrm{K}-\mathrm{W}=19.2469 ;$ \\
\cline { 2 - 4 } & N positive & 104 & $0.000712597(0.0-0.039868)$ & $\mathrm{p}<0.0001$ \\
\hline \multirow{2}{*}{ PLVD } & N negative & 75 & $4.0(0.0-19.0)$ & $\mathrm{K}-\mathrm{W}=0.376007 ;$ \\
& N positive & 104 & $5.5(0.0-20.0)$ & $\mathrm{p}=0.5395$ \\
\hline \multirow{2}{*}{ PRLVA } & N negative & 75 & $0.00465477(0.0-0.0395735)$ & $\mathrm{K}-\mathrm{W}=2.06818 ;$ \\
\cline { 2 - 4 } & N positive & 104 & $0.0030335(0.0-0.0424628)$ & $\mathrm{p}=0.150$ \\
\hline
\end{tabular}

ILVD: Intratumor lymphatic vascular density, IRLVA: Intratumor relative lymphatic vascular area, PLVD: Peritumor lymphatic vascular density, PRLVA: Peritumor relative lymphatic vascular area. 
Analysis of the relationship between intra- and peritumoral lymphatic vascularization and lymph node status demonstrated that both indicators of intratumor vascularization (IRLVA and ILVD) were increased in node positive patients compared to node negative patients.

At the same time, both PRLVA and PLVD were not associated with the axillary lymph node status. Details are presented on Table IV.

\section{DISCUSSION}

The controversy concerning the presence of lymphangiogenesis in breast cancer is open to questions (12,19-24). Breast carcinomas might be divided into morphological (16) or molecular subtypes (1-6) but criteria for the latter are not widely accepted, and several variations in definitions of molecular subtypes of breast carcinomas exist.

Controversies also exist for the score of estrogen receptors (ER). According to ASCO/CAP guidelines, positivity for hormone receptors in breast cancer is considered when more than one percent of the total tumor cell proliferation expresses ER and/or PgR receptors. This threshold for positivity proved useful in clinical practice because of its significance in clinical prognosis and prediction (25). Nevertheless, other authors view the cut-off point of ER/ PgR positivity of $10 \%$ as the minimum percentage of immunopositive tumor cells required to consider hormone receptor positive status (18). Despite the fact that the $10 \%$ positivity threshold for steroid receptors in BC is an old concept in terms of treatment and survival, we believe it is the positivity threshold that has significant meaning for angiogenesis and potentially for lymphangiogenesis as well. As Elkin $\mathrm{M}$ et al. mentioned, $7 \%-17 \%$ is the ER expression in the normal breast epithelium and probably more ER positive tumor cell are needed to induce angiogenesis in BC (26).

The present study confirms the data of the increased lymphatic vascularity associated with HER2 over-expression in the HER2 subtype (14). Accordingly, increased median values of ILVD and IRLVA in invasive HER2 overexpressing but not in all HER2 pathway-driven breast carcinomas (TPT) have been demonstrated. Surprisingly, IRLVA in invasive HER2 tumors was not significantly different from IRLVA in invasive TNT. We believe that this is due to the relatively small area occupied by the greater in number but collapsed intratumor lymphatic vessels.

Increased lymphatic vascularization was seen mostly at the periphery of invasive HER2 tumors a finding that might be interpreted as the result from entrapment of pre-existing vessels by the invading tumor. In such cases, entrapped lymphatic vascularization by the tumor ought to be of the same magnitude as the vessels located within the surrounding unaffected tissue. This was not the case as peritumor lymphatic vascularization (vascularization of morphologically normal breast tissues) was found similar to all the other tumor types which on the other hand had no increased intratumor lymphatic vascularisation. This would indicate that HER2 overexpressing breast carcinomas do have denser lymphovascularization caused by active lymphangiogenesis inside the tumor. Additionally, peritumor lymphatic vascularization parameter PRLVA was found to be significantly increased in HER2 tumors compared to TPT, but since it was not supported by increased peritumor vascular counts, this was accepted as significant dilation of the peritumor vessels.

The present study demonstrates that the patients with positive axillary node status have significantly increased ILVD and IRLVA, compared to patients with negative axillary lymph node status.

Different staining procedures, lack of uniform definition of peri- and intratumor lymphatic vessels and the wide variety of studied breast carcinomas contribute to the presence of serious discrepancies concerning the role of intratumor lymphatic vessels in breast cancer (reviewed in (27)).

One article that defined intra- and peritumor vessels in $\mathrm{BC}$ in accordance with our understanding demonstrated a "significantly higher maximal perimeter of intratumoral and peritumoral lymph vessels" in node positive breast cancer patients. At the same time, lymphatic vascular area and the number of lymphatic vessels were not associated with lymph node status (21). We believe that the present discrepancy with our result might be caused by the fact that the abovementioned study concerned only inflammatory breast cancer.

Results, suggesting the important role of intratumor lymphatic vessels for lymphogenic spread of primary tumors were observed in early gastric cancer (28). In spite of higher lymphangiogenesis in HER2 carcinomas, no statistical difference was present for lymph node metastases with the other types of carcinomas not showing angiogenesis and more specifically axillary node metastases were present in half of the HER2 carcinomas, while axillary nodes were affected in more than half of the cases of SRP, TPT and TNT that were closely matched by tumor size and grade.

An apparent paradox was that even the better differentiated carcinomas with significantly lower median lymphatic vascularity such as tumors from the SRP group had 
metastasized to the axillary lymph nodes more frequently than the HER2 overexpressing carcinomas that were moderately to poorly differentiated neoplasms with relatively higher median lymphatic vascularity. All these data point to the fact that intratumor neoformed lymphatics are of limited functional capacities for generating metastases while preexisting vessels outside the tumor burden are more apt to route tumor emboli.

In conclusion, the present study indicates that HER2 overexpressing tumors have increased intratumor lymphatic vascularization as compared to all other subtypes of breast carcinomas. However, this increase appears to be of low clinical impact since the metastatic rate of HER2 overexpressing breast carcinomas is not higher than that of any other subtype of breast cancer, and probably reflects the fact that the newly formed intratumor lymphatic vessels in invasive HER2 overexpressing breast carcinoma are not fully functional.

\section{ACKNOWLEDGMENTS}

We would like to thank to Vincenzo Eusebi who gave us scientific guidance, and encouraged a clear presentation of our scientific results.

\section{REFERENCES}

1. Bhargava R, Beriwal S, Striebel JM, Dabbs DJ. Breast cancer molecular class ERBB2: preponderance of tumors with apocrine differentiation and expression of basal phenotype markers CK5, CK5/6, and EGFR. Appl Immunohistochem Mol Morphol. 2010;18:113-8

2. Spitale A, Mazzola P, Soldini D, Mazzucchelli L, Bordoni A. Breast cancer classification according to immunohistochemical markers: Clinicopathologic features and short-term survival analysis in a population-based study from the south of Switzerland. Ann Oncol. 2009;20:628-35.

3. Carey LA, Perou CM, Livasy CA, Dressler LG, Cowan D, Conway K, Karaca G, Troester MA, Tse CK, Edmiston S, Deming SL, Geradts J, Cheang MCU, Nielsen TO, Moorman PG, Earp HS, Millikan RC. Race, breast cancer subtypes, and survival in the carolina breast cancer study. JAMA. 2006;295:2492-502.

4. Yu Q, Niu Y, Liu N, Zhang JZ, Liu TJ, Zhang RJ, Wang SL, Ding XM, Xiao XQ. Expression of androgen receptor in breast cancer and its significance as a prognostic factor. Ann Oncol. 2011;22:1288-94

5. Cheang MCU, Voduc D, Bajdik C, Leung S, McKinney S, Chia SK, Perou CM, Nielsen TO. Basal-like breast cancer defined by five biomarkers has superior prognostic value than triple-negative phenotype. Clin Cancer Res. 2008;14:1368.

6. Laakso M, Tanner M, Nilsson J, Wiklund T, Erikstein B, Kellokumpu-Lehtinen P, Malmstrom P, Wilking N, Bergh J, Isola J. Basoluminal carcinoma: A new biologically and prognostically distinct entity between basal and luminal breast cancer. Clin Cancer Res. 2006;12:4185-91.
7. Rakha EA, Elsheikh SE, Aleskandarany MA, Habashi HO, Green AR, Powe DG, El-Sayed ME, Benhasouna A, Brunet JS, Akslen LA, Evans AJ, Blamey R, Reis-Filho JS, Foulkes WD, Ellis IO. Triple-negative breast cancer: Distinguishing between basal and nonbasal subtypes. Clin Cancer Res. 2009; 15:2302-10.

8. Hasebe T, Iwasaki M, Akashi-Tanaka S, Hojo T, Shibata T, Kinoshita $\mathrm{T}$, Tsuda $\mathrm{H}$. Important histologic outcome predictors for patients with invasive ductal carcinoma of the breast. Am J Surg Pathol. 2011;35:1484-97.

9. Onitilo AA, Engel JM, Greenlee RT, Mukesh BN. Breast cancer subtypes based on ER/PR and Her2 expression: Comparison of clinicopathologic features and survival. Clinical Medicine \& Research. 2009;7:(1-2)4-13.

10. Blackwell KL, Dewhirst MW, Liotcheva V, Snyder S, Broadwater G, Bentley R, Lal A, Riggins G, Anderson S, Vredenburgh J, Proia A, Harris LN. HER-2 gene amplification correlates with higher levels of angiogenesis and lower levels of hypoxia in primary breast tumors. Clin Cancer Res. 2004;10:4083-8.

11. Dimmeler S, Zeiher AM. Akt takes center stage in angiogenesis signaling. Circ Res. 2000;86:4-5.

12. Zhang GH, Yang WT, Zhou XY, Zeng Y, Lu H-F, Shi DR. Study of the correlation between HER-2 gene and lymphangiogenesis and their prognostic significance in human breast cancer. Zhonghua Yi Xue Za Zhi. 2007;87:155-60.

13. Schoppmann SF, Tamandl D, Roberts L, Jomrich G, Schoppmann A, Zwrtek R, Dubsky P, Gnant M, Jakesz R, Birner P. HER2/neu expression correlates with vascular endothelial growth factor-C and lymphangiogenesis in lymph node-positive breast cancer. Ann Oncol. 2009;21:955-60

14. Raica M, Cimpean AM, Ceausu R, Ribatti D. Lymphatic microvessel density, VEGF-C, and VEGFR-3 expression in different molecular types of breast cancer. Anticancer Res. 2011;31:1757-64.

15. Tavassoli FA, Devillee P. WHO Classification of Tumours: Pathology and genetics of tumours of the breast and female genital organs, Lyon: IARC Press; 2003. 11-58.

16. Elston CW, Ellis IO. Pathological prognostic factors in breast cancer. The value of histological grade in breast cancer: Experience from a large study with long-term follow-up. Histopathology. 2002;41:154-61

17. Wolff AC, Hammond MEH, Schwartz JN, Hagerty KL, Allred DC, Cote RJ, Dowsett M, Fitzgibbons PL, Hanna WM, Langer A, McShane LM, Paik S, Pegram MD, Perez EA, Press MF, Rhodes A, Sturgeon C, Taube SE, Tubbs R, Vance GH, van de Vijver M, Wheeler TM, Hayes DF, American Society of Clinical Oncology/ College of American Pathologists. Guideline recommendations for Human Epidermal Growth Factor Receptor 2 testing in breast cancer. Arch Pathol Lab Med. 2007;131:18-34.

18. Dowsett M, Allred C, Knox J, Quinn E, Salter J, Wale C, Cuzick J, Houghton J, Williams N, Mallon E, Bishop H, Ellis I, Larsimont D, Sasano H, Carder P, Llombart Cussac A, Knox F, Speirs V, Forbes J, Buzdar A. Relationship between quantitative estrogen and progesterone receptor expression and human epidermal growth factor receptor 2 (HER-2) status with recurrence in the Arimidex, Tamoxifen, alone or in combination trial. J Clin Oncol. 2008;26:1059-65. 
19. Cunnick GH, Jiang WG, Douglas-Jones T, Watkins G, Gomez KF, Morgan MJ, Subramanian A, Mokbel K, Mansel RE. Lymphangiogenesis and lymph node metastasis in breast cancer. Mol Cancer. 2008;7:23.

20. Karpanen T, Egeblad M, Karkkainen MJ, Kubo H, Ylä-Herttuala S, Jäättelä M, Alitalo K. Vascular Endothelial Growth Factor C promotes tumor lymphangiogenesis and intralymphatic tumor growth. Cancer Res. 2001;61:1786-90.

21. van der Auwera I, Van den Eynden G, Colpaert C, Van Laere S, van Dam P, Van Marck E, Dirix L, Vermeulen P. Tumor lymphangiogenesis in inflammatory breast carcinoma: A histomorphometric study. Clin Cancer Res. 2005;11:7637-42.

22. Agarwal B, Saxena R, Morimiya A, Mehrotra S, Badve S. Lymphangiogenesis does not occur in breast cancer. Am J Surg Pathol. 2005;29:1449-55.

23. Vleugel M, Bos R, van der Groep P, Greijer A E, Shvarts A, Stel $\mathrm{HV}$, van der Wall E, van Diest PJ. Lack of lymphangiogenesis during breast carcinogenesis. J Clin Pathol. 2004;57:746-51.

24. Williams C, Leek R, Robson A, Banerji S, Prevo R, Harris A, Jackson D. Absence of lymphangiogenesis and intratumoural lymph vessels in human metastatic breast cancer. J Pathol. 2003;200:195-206.
25. Hammond MEH, Hayes DF, Dowsett M, Allred DC, Hagerty KL, Badve S, Fitzgibbons PL, Francis G, Goldstein NS, Hayes M, Hicks DG, Lester S, Love R, Mangu PB, McShane L, Miller K, Osborne CK, Paik S, Perlmutter J, Rhodes A, Sasano H, Schwartz JN, Sweep FCG, Taube S, Torlakovic EE, Valenstein P, Viale G, Visscher D, Wheeler T, Williams RB, Wittliff JL, Wolff AC. American Society of Clinical Oncology/College of American Pathologists Guideline Recommendations for Immunohistochemical Testing of Estrogen and Progesterone Receptors in Breast Cancer (Unabridged Version). Arch Pathol Lab Med. 2010;134:e48-e72.

26. Elkin M, Orgel A, Kleinman HK An angiogenic switch in breast cancer involves estrogen and soluble vascular endothelial growth factor receptor 1. J Natl Cancer Inst 2004;96:875-8.

27. Alitalo A, Detmar M. Interaction of tumor cells and lymphatic vessels in cancer progression. Oncogene. 2012;31:4499-508.

28. Lee K, Park do J, Choe G, Kim HH, Kim WH, Lee HS. Increased intratumoral lymphatic vessel density correlates with lymph node metastasis in early gastric carcinoma. Ann Surg Oncol. 2010;17:73-80. 